Krzysztof Bokwa*

ORCID: 0000-0002-7625-6809

Iwo Jarosz $z^{* *}$

ORCID: 0000-0003-3671-1982

Uniwersytet Jagielloński

DOI: $10.19195 / 1733-5779.25 .7$

\title{
Czy na pewno martwa instytucja? \\ Staropolskie i austriackie pactum advitalitium w perspektywie współczesnej
}

\section{JEL Classification: K36}

Słowa kluczowe: prawo austriackie, prawo staropolskie, użytkowanie, prawo cywilne, historia prawa

Keywords: Austrian law, old-Polish law, usufruct, civil law, legal history

\begin{abstract}
Abstrakt: Pactum advitalitium stanowiło pierwotnie instytucję prawa staropolskiego. Była to umowa majątkowa, na podstawie której małżonkowie ustanawiali wzajemnie na swoją rzecz prawo użytkowania całości swoich majątków na wypadek śmierci. Praktycznym jej celem było zapewnienie bytu materialnego owdowiałemu małżonkowi (zwykle żonie), a to ze względu na brak wspólności majątkowej oraz ustawowego spadkobrania po małżonku. Po rozbiorach instytucję tę przejął ustawodawca austriacki, umieszczając ją w ABGB, acz z pewnymi zmianami - na przykład umożliwiając obciążenie nie tylko całego majątku, lecz także poszczególnych jego składników. W ten sposób advitalitium stało się kontraktem możliwym do zawarcia w całym Cesarstwie Austriackim, nie zyskało jednak popularności; już w XXI wieku instytucja ta została wykreślona z kodeksu austriackiego. Charakter prawny advitalitium był i pozostaje kontrowersyjny, co prowadziło do wysuwania w doktrynie różnorodnych teorii odnośnie do jego natury (niekiedy uzależniających ją od jego przedmiotu). Autorzy podejmują próbę zbadania advitalitium w kontekście historycznym, odnosząc się zarazem do koncepcji doktrynalnych z epoki. W tym celu zostają użyte metody badawcze: historyczna oraz formalno-dogmatyczna. Następnie autorzy analizują możliwość osiągnięcia skutków identycznych lub podobnych do advitalitium na gruncie współczesnego prawa polskiego, wykorzystując w tym celu metodę formalno-dogmatyczną; pozwala to na wykazanie, że w polskim porządku prawnym nie tylko nieobecna jest instytucja odpowiadająca
\end{abstract}

\footnotetext{
* Opiekun naukowy (Scientific Tutor) - Andrzej Dziadzio

** Opiekun naukowy (Scientific Tutor) — Fryderyk Zoll
} 
advitalitium, lecz także, że osiągnięcie analogicznego doń efektu nie jest możliwe w obowiązującym stanie prawnym. W tym kontekście autorzy kończą swe rozważania refleksją na temat ewentualnej przydatności advitalitium dla celu estate planning w kontekście współczesnych relacji rodzinnych; być może na tym gruncie zasadne byłoby odrodzenie tej instytucji prawnej.

\title{
An already defunct institution? Old-Polish and Austrian pactum advitalitium in a contemporary perspective
}

\begin{abstract}
Pactum advitalitium was an early Polish legal institution established through a marital agreement. It was a form of annuity by means of which spouses established a right of usufruct of the entirety of an estate, effective upon the passing of one spouse and existing for the lifetime of the beneficiary. The practical purpose thereof was to secure the material well-being of a widowed spouse, usually the wife, given not only that the legal system did not provide for commune marital property, as well as that there was no statutory spousal succession. Later, after the partitions of Commonwealth of Poland and Lithuania, the institution discussed herein was adopted by Austrian law and regulated in the newly enacted Austrian Civil Code (ABGB), with slight modifications enabling i.a. to encumber not only the whole estate or a part thereof, but also several assets of a future estate. Thus advitalitium had become available within the vast Austrian Empire, yet it did not gain a wide recognition among the nations of the Monarchy, remaining an infrequently used institution, which led to its repeal in 21 st century. The very legal character of pactum advitalitium was and is still controversial, leading the academia to suggest multiple explanations of its nature, often varying significantly dependent on the subject of advitalitium in a specific case (the entirety of an estate or a part thereof or several assets). The authors aim to examine the origins and history of advitalitium regulation in early Polish and Austrian law in their historical context, later to recount the doctrinal concepts explaining its character. To pursue both there aims, historical and formal-dogmatic methods are employed. The authors then move on to discuss the possibility of reaching results identical or just similar to ones achieved by means of an advitalitium in modern Polish law, applying the formal-dogmatic method, to show that not only no comparable institution exists in Polish law nowadays but, moreover, that similar results cannot be achieved by applying instruments known to Polish law. Such analysis enables the authors to arrive at conclusions regarding the possible application of advitalitium as an instrument of estate planning in the context of modern family relationships, which could lead to the rediscovery thereof in modern legal systems.
\end{abstract}

\section{Wstęp}

Z chwilą pierwszego rozbioru Polski w 1772 roku znaczne obszary Polski południowej znalazły się pod berłem Habsburgów jako Królestwo Galicji i Lodomerii, które to miano miało swe źródło jeszcze w średniowiecznych, węgierskich pretensjach do ziem Księstwa Halicko-Włodzimierskiego ${ }^{1}$. Tereny te aż do 1918 roku pozostały częścią wielonarodowego państwa austriackiego. Jedną z konsekwencji tej sytuacji była niemal natychmiastowa, bezpardonowa likwidacja staropolskiego systemu prawnego, mającego jeszcze korzenie średniowieczne; w Polsce nie powiodła się bowiem nawet częściowa kodyfikacja prawa prywatnego. Funkcjonowały ciągle prowincjonalne partykularyzmy oraz stanowy podział na prawo ziemskie,

1 Zob. S. Grodziski, W Królestwie Galicji i Lodomerii, Kraków 2005, s. 11-15. 
miejskie i wiejskie. Ta różnorodność tworzyła fundament mocnej, wolnościowej tradycji Rzeczypospolitej Obojga Narodów, bezpowrotnie zniszczonej w wyniku rozbiorów.

W efekcie aż do lat 60. XIX wieku Polacy galicyjscy powszechnie postrzegali austriacką władzę i prawo jako obce, narzucone. Tę sytuację zmieniła dopiero przebudowa wewnętrzna Cesarstwa Austrii na liberalną, konstytucyjną Monarchię Austro-Węgierską, która dokonała się w latach 60. XIX wieku². Dzięki niej Polacy w Galicji uzyskali szeroką autonomię i bezpośredni wpływ na życie polityczne całej Austrii — również w kwestiach prawnych. Język polski stał się językiem oficjalnym w sądach i urzędach, zaś wielu Polaków osiągnęło najwyższe pozycje w polityce i administracji nowej, parlamentarnej i konstytucyjnej Austrii ${ }^{3}$.

Polski wpływ na prawo austriackie nie ograniczał się jednak do kwestii personalnych i jego obowiązywania na historycznym terytorium polskim. Jak już wspomniano, staropolski system prawny był nie do pogodzenia z nowym, „oświeconym" prawem, które intensywnie tworzono w Austrii w drugiej połowie XVIII wieku. Wtedy to, na fali szeroko zakrojonej józefińskiej akcji modernizacyjnej, weszła w życie pierwsza, niepełna austriacka kodyfikacja prawa cywilnego (Codex Josephinus). Pierwszą pełną kodyfikacją był jednak Kodeks Cywilny Zachodniogalicyjski z 1797 roku, przez niektórych uznawany za pierwszą na świecie nowoczesną kodyfikację prawa prywatnego. Stanowiła ona „wersję próbną” powszechnej kodyfikacji cywilnej dla całej Austrii, tj. ABGB, obowiązującego od 1811 roku aż do chwili obecnej.

ABGB był kodeksem nowoczesnym, czerpiącym przede wszystkim ze szkoły prawa natury, znoszącym podziały stanowe i prowincjonalne partykularyzmy. Tym samym był to akt ostatecznie grzebiący dziedzictwo prawa staropolskiego w Galicji. Jak już jednak wspomniano, jego powstanie było owocem wieloletnich wysiłków, które oprócz działań stricte legislacyjnych obejmowały także swoiste „konsultacje społeczne” — w dyskusje nad kodyfikacją byli zaangażowani zarówno uczeni, jak i praktycy prawa z całej Monarchii Habsburgów. Ich owocem było włączenie do ABGB instytucji typowej dla prawa staropolskiego - umowy dożywocia, pactum advitalitium.

\section{Advitalitium staropolskie}

Prawo staropolskie zakładało odrębność majątkową osobistych majątków żony i męża, nie znając instytucji małżeńskiego majątku wspólnego ${ }^{4}$. Z odrębności ma-

2 Zob. H. Wereszycki, Pod bertem Habsburgów, Kraków 1986, s. 181-195.

3 Zob. K. Bokwa, Odszkodowanie oraz zadośćuczynienie w prawie polskim i austriackim. Rys historyczny i prawnoporównawczy, [w:] Pomniki prawa na przestrzeni wieków, red. K. Górski et al., Kraków 2017, s. 132-133.

4 Jedyną formą wspólności było współużytkowanie, tj. wspólne korzystanie z majątków przez małżonków. Zob. P. Dąbkowski, Prawo prywatne polskie, t. 1, Lwów 1910, s. 418. 
jątków obu małżonków wywodzono generalną swobodę dokonywania czynności prawnych prowadzących do przesunięć pomiędzy tymi majątkami ${ }^{5}$. Jednocześnie ustawowy porządek dziedziczenia wykluczał spadkobranie małżonków po sobie - zaś reguły odnoszące się do sporządzania testamentów nie dozwalały na dokonywanie zapisów odnoszących się do dóbr nieruchomych, stanowiących w owym czasie podstawę gospodarki, i, jako czynnik produkcji o znaczeniu daleko większym aniżeli współcześnie, najistotniejszy składnik majątków.

Prawo polskie okresu średniowiecza przewidywało uprawnienie żony polegające na możliwości korzystania po śmierci męża $z$ dóbr składających się na wiano ${ }^{6}$. Stanowiło ono pewną kwotę pieniężną zabezpieczoną na majątku męża, mającą stanowić formę odwzajemnienia za wniesiony posag. Zabezpieczenie posagu i wiana zwano łącznie oprawą ${ }^{8}$. W praktyce celem, który wiano miało spełniać, było zapewnienie żonie podstaw utrzymania po śmierci męża. Początkowo w prawie polskim, jak się wydaje, mianem dożywocia (advitalitas) określano posag i wiano - z uwagi na prawo dożywotniego użytkowania tych dóbr ${ }^{9}$ przez kobietę (pozostającą in sede viduali). Po śmierci żony lub w razie jej powtórnego zamążpójścia oprawione dobra wracały do rodziny męża.

Rozwiązanie takie miało jednak pewne cechy warunkujące powstanie instytucji dożywocia o kształcie inkorporowanym później do prawa austriackiego. Zapis dóbr oprawnych na rzecz żony wyłączał swobodne nimi dysponowanie przez męża, konstrukcyjnie oparty na braku zaufania do niego ${ }^{10}$. Jednocześnie formuła zabezpieczenia powodowała, że wypłata kwoty posagu i wiana w gotówce do rąk wdowy zwalniała dobra oprawne z obciążenia. Było to naturalnie korzystne dla agnatów zmarłego męża. Z punktu widzenia wdowy mogło jednak spowodować, przy niskiej wielkości wiana zabezpieczonego na dobrach znacząco pomnożonych za życia męża, dość łatwe i niekorzystne dla niej wyzucie jej z prawa korzystania z oprawionych dóbr. Nie dziwi zatem, że popularność zyskiwało dożywocie (advitalitas, advitalitium, inscriptio ad tempora vitae $)^{11}$. Polegało ono na wzajemnym ustanowieniu przez małżonków, na wypadek śmierci, prawa dożywotniego użytkowania majątku na korzyść drugiego.

Advitalitium kreowało prawo dożywotniego użytkowania (usufructus) dóbr spadkowych, przy jednoczesnym jednak przejściu tytułu ich własności na rzecz spadkobierców (prowadziło zatem do odsunięcia w czasie chwili wydania spad-

5 Ibidem.

6 P. Dąbkowski, op. cit., s. 421.

${ }^{7}$ Na temat genezy i rozwoju form odpłaty za posag oraz ich zabezpieczania na dobrach męża zob. A. Winiarz, Polskie prawo majątkowe-matżeńskie w wiekach średnich, Kraków 1899, s. 166-175.

8 W. Spasowicz, Pisma, t. 4, Petersburg 1892, s. 11.

9 A. Winiarz, op. cit., s. 211.

10 W. Spasowicz, op. cit., s. 32.

11 Pierwszą wzmiankę o nim w ustawodawstwie polskim znajdziemy w wydanym za Zygmunta I formularzu aktów najczęściej używanych, Volumina Legum I, 419. 
ku objętego prawem dożywocia spadkobiercom oraz jego podziału, zasadniczo aż do śmierci obojga rodziców). Do istotnych elementów advitalitium należała wzajemność - zapis niewzajemny mógł podlegać obaleniu przez spadkobierców zmarłego małżonka. Dożywotnik miał prawo korzystać z majątku, wraz z pobieranymi pożytkami, pozbawiony był jednak możliwości zbywania go, uszczuplania, obciążania prawami wieczystymi bądź czasowymi ${ }^{12}$.

Dożywocie upadało w przypadku zrzeczenia się go oraz nadużycia praw z niego wynikających, ale też w razie rozwiązania małżeństwa przez rozwód, małżonkobójstwa, niespełnienia warunku, pod jakim dożywocie zostało ustanowione (w tym zakresie na pierwszy plan wysuwa się często zastrzegany warunek rozwiązujący powtórne zamążpójście), a także tzw. nieoczyszczenia dożywocia, tj. niespłacenia długów ciążących na majątku będącym przedmiotem advitalitium ${ }^{13}$.

\section{Pactum advitalitium w prawie austriackim}

Możliwość zawierania opisanych umów dożywocia utrzymano na wcielonych do Austrii południowych ziemiach polskich za pośrednictwem szczególnych dekretów nadwornych, jednak nie zawarto jej w Kodeksie Cywilnym Zachodniogalicyjskim. Spotkało się to ze sprzeciwem szlachty polskiej, wyrażonym w uwagach do nowej kodyfikacji, zgłoszonych przez trybunał ziemski (forum nobilium, sąd I instancji) w Tarnowie w 1797 roku $^{14}$. Między innymi pod ich wpływem obszerny wniosek o włączenie staropolskiego pactum advitalitium do ABGB złożył C.J. Pratobevera ${ }^{15}$, który znał je dzięki dziesięcioletniemu pobytowi w Krakowie ${ }^{16}$. W ten sposób instytucja ta stała się jedynym okruchem dorobku staropolskiego prawa ziemskiego ${ }^{17}$, który znalazł swe miejsce w nowej austriackiej kodyfikacji.

W ABGB przepisy o użytkowaniu na wypadek śmierci (Fruchtnießung auf den Todesfall, Advitalitäts-Recht) umieszczono w rozdziale 28, dotyczącym kontraktów małżeńskich ${ }^{18}$. Kategoria ta obejmowała między innymi umowy dotyczące ustroju majątkowego małżeńskiego, posagu, wiana, zarządu i użytkowania mająt-

12 P. Dąbkowski, op. cit., s. 443.

13 Ibidem, s. 446.

14 Tak E. Till, Obrady trybunatu szlacheckiego w Tarnowie: o t.z.w. galicyjskim kodeksie cywilnym z roku 1797, Lwów 1909.

15 Carl Joseph Pratobevera von Wiesborn (1769-1853), jeden z najwybitniejszych prawników austriackich pierwszej połowy XIX wieku, uczeń Sonnenfelsa i Zeillera; w latach 1796-1806 sędzia sądu apelacyjnego w Krakowie, wykładał nowe prawo austriackie na Uniwersytecie Jagiellońskim i był jego rektorem; później sędzia sądu apelacyjnego w Wiedniu, profesor Uniwersytetu Wiedeńskiego. Zob. https://www.deutsche-biographie.de/sfz97128.html (dostęp: 18.08.2018).

16 E. Till, op. cit., s. 11-12.

17 Podobne instytucje występowały także w dawnym prawie niemieckim. Zob. A. Ogonowski, Oesterreichisches Ehegüterrecht, t. 1., Leipzig 1880, s. 374-375.

18 Tłumaczonych też jako układy małżeńskie, intercyzy; niem. Ehepakt. 
ku oraz właśnie advitalitium, uregulowane w $\S$ 1255-1258. Definicję użytkowania na wypadek śmierci zawarto w pierwszym $\mathrm{z}$ tych przepisów ${ }^{19}$ :

$\S 1255$. Jeżeli małżonek udzielił drugiemu użytkowanie swojego majątku na przypadek przeżycia, nie zostaje przez to ograniczony w swobodnem rozporządzaniu nim zapomocą czynności między żyjącymi; prawo użytkowania (§§ 509-520) odnosi się tylko do spuścizny wolno dziedziczonego majątku ${ }^{20}$.

Staropolskie pochodzenie uregulowanej w ten sposób instytucji zaznaczył sam F. Zeiller w autorskim komentarzu do $\mathrm{ABGB}^{21}$; zasadniczo była ona podobna do ustawowego prawa użytkowania części spadku, przysługującej małżonkowi na gruncie $\S \S 757 \mathrm{n} . \mathrm{ABGB}^{22}$. Do tych przepisów odniesiono się w $\S 1258$, wskazując, że w razie ustanowienia umownego użytkowania na wypadek śmierci ich stosowanie jest wyłączone; w razie tego rodzaju kolizji przyjmowano jednak, że uprawniony małżonek ma prawo wybrać, z którego z uprawnień chce skorzystać ${ }^{23}$. W prawie austriackim advitalitium mogło być zarówno wzajemne, jak i ustanowione tylko na rzecz jednego z małżonków ${ }^{24}$, mogło być również odpłatne ${ }^{25}$. Prawa,

19 Tłumaczenie za: S. Wróblewski, Powszechny austryacki kodeks cywilny z uzupetniającemi ustawami i rozporządzeniami, objaśniony orzeczeniami Sądu Najwyższego. Część druga (\$\$ 9381502), Kraków 1918, s. 1060; pisownia oryginalna zachowana. Pozostałe przepisy dotyczące advialitium miały w tym samym tłumaczeniu następujące brzmienie: „§ 1256. Jeżeli jednak użytkowanie nieruchomości za zgodą nadającego wpisano do ksiąg publicznych; nie może ono co do tej nieruchomości doznać uszczuplenia. § 1257. Jeżeli pozostały przy życiu małżonek wejdzie w nowe związki małżeńskie, albo użytkowanie komu innemu chce odstąpić, natenczas dzieci zmarłego małżonka mają prawo żądać, aby im odstąpiono to użytkowanie za odpowiednią roczną opłatą. $\S 1258$. Małżonek, który rości sobie prawo do użytkowania całej spuścizny po drugim małżonku lub części tejże, nie ma prawa żądać udziału, jaki mu wyznacza ustawa na przypadek dziedziczenia z ustawy (\$§ 757-759)".

${ }^{20}$ Choć starsze o przeszło stulecie, to nieco lepiej oddające istotę przepisu wydaje się w tym wypadku oryginalne tłumaczenie tego przepisu autorstwa Macieja Stojowskiego, pochodzące z 1811 roku: „Gdy ieden małżonek nadaie drugiemu pobiéranie dochodów z swego maiątku, na przypadek przeżycia; tedy przez to nadaiący nie iest ograniczony w wolném zarządzaniu, i władaniu przez czynności między żyiącemi; prawo pobiérania dochodów (§. 509-520.) ściąga się tylko do spadku, wolno odziedziczonego, rozporządzeniem ostatniey woli nie zaiętego majątku". Cyt. za: Księga Ustaw Cywilnych Wszystkim Niemiecko-Dziedzicznym Kraiom Monarchyi Austryackiey Powszechna, Wiedeń 1811, s. 412.

${ }^{21}$ F. von Zeiller, Commentar über das allgemeine bürgerliche Gesetzbuch für die gesamten Deutschen Erblander der Oesterreichischen Monarchie. Dritter Band, Zweyte Abtheilung, Wien-Triest 1813, s. 640.

${ }^{22}$ Aż do XX wieku małżonek był w Austrii dziedzicem ustawowym tylko w sytuacji braku bliskich krewnych; zob. § 758-759 ABGB w wersji z 1811 roku.

23 M. Lakner, Ueber die Abfassung von Testamenten, so wie über das Erbrecht und die Erbschaftsangelegenheiten, Wien 1853, s. 105.

24 F. von Zeiller, op. cit., s. 641.

25 J. von Winiwarter, Das österreichische bürgerliche Recht, systematisch dargestellt und erläutert. Vierter Theil, Wien 1837, s. 462. 
jakie uzyskiwał małżonek-beneficjent, nie różniły się zasadniczo od ogólnie regulowanego prawa użytkowania ( $\S 509-520$ ABGB).

Ze względu na swą specyfikę advitalitium wywoływało w doktrynie austriackiej spore problemy kwalifikacyjne. Będąc rodzajem umowy mortis causa, wykazywało podobieństwo zarówno do umowy o dziedziczenie, darowizny na wypadek śmierci, jak i zapisu windykacyjnego. Ocenę dodatkowo komplikowało różne interpretowanie advitalitium zależnie od jego przedmiotu i podstawy prawnej — po pierwsze więc zależnie od tego, czy dotyczyło masy majątkowej (całości lub część spadku), czy poszczególnych przedmiotów, a po drugie zależnie od tego, jaka była forma jego ustanowienia - umowna czy jednostronna.

Omawiając instytucję advitalitium w ujęciu staropolskim, przypisywano jej charakter umowy zawieranej pomiędzy małżonkami ${ }^{26}$ i określającej ich stosunki majątkowe w sposób odmienny od przepisanego normami dyspozytywnymi. Takie ujęcie dziś uznalibyśmy za charakterystyczne dla umowy majątkowej małżeńskiej. Inne stanowiska zasadzały się na uznaniu advitalitium, pomimo określenia tej instytucji jako ,umowy urządzającej stosunki majątkowe między małżonkami” (a więc analogicznie do austriackiej regulacji jako typu kontraktu małżeńskiego), za spadek umowny ${ }^{27}$, wskazując, że przesądzają o tym takie cechy, jak odnoszenie się dożywocia do majątku spadkowego czy wejście w życie z chwilą śmierci jednego z małżonków.

W doktrynie austriackiej różnice zdań były jeszcze większe. I tak F.X. Nippel twierdził, że charakter advitalitium jest zależny od jego przedmiotu. Jeśli chodziło o użytkowanie na wypadek śmierci całego majątku bądź jego części, to, jego zdaniem, zachodził szczególny typ umowy o dziedziczenie (Erbvertrag); jeżeli jednak przedmiotem użytkowania były rzeczy konkretne lub określone co do gatunku, wówczas uznawał to za rodzaj darowizny na wypadek śmierci lub - jeśli nie dopełniono jej wymogów formalnych - za zapis ${ }^{28}$. Bezspornie dopuszczano bowiem ustanowienie na wypadek śmierci użytkowania masy spadkowej, jej części lub poszczególnych składników, w drodze zapisu testamentowego (a zatem w drodze czynności jednostronnej ${ }^{29}$ lub darowizny mortis causa; co oczywiste, w ten sposób można było również ustanowić użytkowanie na rzecz osób trzecich, jednak wówczas nie było to już advitalitium ${ }^{30}$.

Za rodzaj umowy o dziedziczenie, niezależnie od jej przedmiotu, uznawali advitalitium T. Dolliner i M. von Stubenrauch ${ }^{31}$, z czym jednak nie zgadzali się

26 Tak: W. Spasowicz, op. cit., s. 25.

27 P. Burzyński, Prawo polskie prywatne, Kraków 1871, s. 297.

28 F.X. Nippel, Darstellung der Rechte der Ehegatten in Beziehung auf ihr Vermögen, Linz 1824, s. 183.

29 F. von Zeiller, op. cit., s. 641.

30 J. von Winiwarter, op. cit., s. 461.

31 A. Ogonowski, op. cit., s. 369. 
A. Ogonowski oraz J. von Winiwarter, który wskazywał, że kontrakt ten nie dotyczy nabycia całości praw i obowiązków, co jest istotą spadkobrania, a jedynie tworzy określone (acz przyszłe) prawo rzeczowe w postaci użytkowania na spadkowej masie majątkowej ${ }^{32}$. Ten sam autor stwierdzał, że pactum advitalitium nie stanowi również darowizny mortis causa, gdyż ta nie zaliczała się do kontraktów małżeńskich i dokonać jej można było na rzecz każdego, nie tylko małżonka.

Na podobnym stanowisku stawali także inni przedstawiciele doktryny. Joseph Ellinger konstatował krótko, że ,advitalitium nie jest ani umową o spadek, ani darowizną mortis causa, ale swoistym, odrębnym typem kontraktu małżeńskiego" "33; podobnie M. Lakner ograniczał się do stwierdzenia, że advitalitium jest czymś pomiędzy umową o dziedziczenie a darowizną na wypadek śmierci ${ }^{34}$. Jeszcze inaczej kwestię tę postrzegał jednak S. Wróblewski, stwierdzając, iż ,advitalitium jest co do swej istoty darowizną mortis causa, stanowi jednak specyalny jej przypadek, zaliczony do układów małżeńskich i zbliżony najbardziej do kontraktu dziedziczenia" 35 .

Wskazane kontrowersje rodziły również dylematy odnośnie do formy pactum advitalitium. Zgodnie z koncepcją Winiwartera nie było konieczności zachowania szczególnych wymogów przewidzianych zarówno dla umowy o dziedziczenie, jak i dla darowizny na wypadek śmierci — jak argumentował, podobnych wymogów nie było również w prawie staropolskim ${ }^{36}$.

Niezależnie jednak od wyżej zarysowanych, żywych dyskusji doktrynalnych, praktyczne znaczenie użytkowania na wypadek śmierci było niewielkie — w czasach Cesarstwa (do 1918 roku) instytucja ta miała zastosowanie właściwie jedynie na terenie Galicji, i to również niezbyt częste, o czym świadczy znikoma liczba spraw dotyczących bezpośrednio Advitalitäts-Recht rozpatrywanych przez Sąd Najwyższy w Wiedniu ${ }^{37}$. Po rozpadzie Austro-Węgier ABGB wciąż obowiązywał między innymi na terenie Republiki Austrii, a zatem w mocy pozostała także regulacja advitalitium, jednakże w istocie stając się martwą. Stąd też wykreślenie jej z kodeksu, które nastąpiło z dniem 31 grudnia 2009 roku przy okazji reformy prawa spadkowego ${ }^{38}$, nie wzbudziło żadnej kontrowersji ${ }^{39}$.

32 J. von Winiwarter, op. cit., s. 466.

33 Cyt. za: A. Ogonowski, op. cit., s. 369.

34 M. Lakner, op. cit., s. 104.

35 S. Wróblewski, op. cit., s. 1060.

36 J. von Winiwarter, op. cit., s. 467.

37 Sammlung von civilrechtlichen Entscheidungen des k.k. Obersten Gerichtshofes Achtzehnter Band, red. J. Glaser, J. Unger, J. von Walther, Wien 1883, s. 572.

38 Familienrechts-Änderungsgesetz 2009 - FamR ÄG 2009, BGBl. I Nr 75/2009.

39 Kurzkommentar zum ABGB, red. H. Koziol, P. Bydlinski, R. Bollenberger, Wien 2007, s. 1401. 


\section{Współczesne prawo polskie a pactum advitalitium}

Przenosząc powyższe rozważania na współczesny grunt, warto rozważyć, czy instytucja tożsama $\mathrm{z}$ advitalitium mogłaby funkcjonować obecnie w systemie polskiego prawa cywilnego. Nie budzi wątpliwości brak analogicznej regulacji w ustawodawstwie polskim. W ślad za tym zasadne wydaje się pytanie o możliwość osiągnięcia przez małżonków tożsamych z advitalitium skutków pomimo braku jego nominalnej regulacji, a jeśli tak — jak należałoby ocenić charakter prawny tak rozumianego dożywocia i jakiej kategorii należałoby je przyporządkować w systematyce współczesnego polskiego prawa cywilnego?

Nie ulega wątpliwości, że istotą advitalitium jest ustanowienie użytkowania. $\mathrm{W}$ prawie polskim jest ono ograniczonym prawem rzeczowym, uprawniającym do używania rzeczy i pobierania jej pożytków (art. 252 k.c.). Prawo to za przedmiot może mieć nie tylko rzecz, lecz także zespół środków produkcji (co niewątpliwie jest presuponowane przez art. 257 § 1 k.c.), a także prawa (art. 265 k.c.). Jak wskazano, na gruncie pactum advitalitium w prawie austriackim możliwe było zarówno obciążenie rzeczy, jak i — podobnie jak w prawie staropolskim — całego majątku lub ułamkowo określonej jego części. Czy polska regulacja prawa użytkowania dopuszcza taki przypadek? Odpowiedź na to pytanie musi być negatywna.

Lektura treści ustawy nie uprawnia do wyciągania wniosku o możliwości obciążenia użytkowaniem mas majątkowych ${ }^{40}$ innych aniżeli zespół środków produkcji, tj. zbiór rzeczy lub praw ${ }^{41}$, znamienny stopniem organizacji pozwalającym uznać go za gospodarczą całość, charakteryzującym się zastępowalnością jego składników (co, obok literalnego brzmienia ustawy, dowodzi, że prawo użytkowania ciąży w takim wypadku na całym zbiorze, a nie z osobna na wszelkich jego elementach). Jako przykłady zespołów środków produkcji w rozumieniu art. 257 $\S 1$ k.c. wymienia się na przykład przedsiębiorstwo (w rozumieniu art. $55^{1}$ k.c.) oraz gospodarstwo rolne (art. $55^{3}$ k.c.). Spadek jako masa majątkowa z pewnością nie jest takim zespołem. Konkluzja taka nie budzi wątpliwości doktryny polskiej, wykluczającej możliwość obciążenia prawem użytkowania całego spadku ${ }^{42}$.

Dalszy problem nastręcza forma ewentualnego ustanowienia advitalitium na gruncie współczesnego prawa polskiego. Jak wskazano, umowa o ustanowienie użytkowania na rzecz małżonka na wypadek śmierci została przez ustawodawcę austriackiego sklasyfikowana jako jeden z kontraktów małżeńskich (intercyz). Czy zatem możliwe byłoby skonstruowanie tego rodzaju umowy majątkowej małżeń-

40 Odmiennie niż prawo austriackie, a także na przykład prawo niemieckie, por. § 1085 BGB.

41 P. Księżak, [w:] Kodeks cywilny. Komentarz, red. K. Osajda, Legalis/el. 2018, komentarz do art. 252 k.c., teza 1.

42 Tak np. E. Gniewek, [w:] System Prawa Prywatnego, t. 4. Prawo rzeczowe, red. E. Gniewek, Warszawa 2012, s. 370-371; P. Księżak, op. cit., komentarz do art. 252 k.c., teza 22; J. Kępiński, I. Czarnota, [w:] Kodeks cywilny, t. 1. Komentarz. Art. 1-44911, red. M. Gutowski, Legalis/el. 2016, komentarz do art. 252, nb. 7. 
skiej? Odpowiedź musi być negatywna - prawo polskie zakłada numerus clau$s u s^{43}$ umów majątkowych małżeńskich, co więcej, ograniczając w ogóle pierwotnie ich przedmiotowy zakres do umów kształtujących ustrój majątkowy małżeński według ich bezwzględnie określonej w k.r.o. ${ }^{44}$ klasyfikacji. Czynności polegającej na ustanowieniu na rzecz małżonka prawa użytkowania majątku spadkowego nie sposób zaliczyć do czynności ustanawiających ustrój majątkowy, co przesądza o niemożności ustanowienia advitalitium tą drogą.

Kolejną trudnością z punktu widzenia zastosowania instytucji advitalitium we współczesnym prawie polskim jest ta wynikająca z generalnej niedopuszczalności zawierania umów o spadek po osobie żyjącej — innych aniżeli wprost uregulowana w k.c. umowa zrzeczenia się dziedziczenia ${ }^{45}$ — przepisanej w art. 1047 k.c. Artykuł 941 k.c. czytany wraz z art. 1047 k.c. stanowi, że jedynymi sposobami powołania do dziedziczenia w prawie polskim są ustawa oraz testament. $\mathrm{Z}$ art. 1047 k.c. nie wynika jednak tylko nieważność umownego powołania do dziedziczenia. Sposób wysłowienia tego przepisu, w communis opinio doktryny i orzecznictwa, przesądza o niedopuszczalności zawierania umów mających za przedmiot spadek lub ułamkową jego część. Istotne z punktu widzenia zakazu $\mathrm{z}$ art. 1047 k.c. jest traktowanie rzeczy i praw jako spadku, ich wyróżnienie jako masę majątkową o statusie spadku, choćby przyszłego. Zatem w każdym przypadku, gdy przedmiotem umowy jest ogół praw i obowiązków danej osoby w chwili śmierci, dopatrywać by się w niej trzeba umowy o spadek, co winno skutkować konkluzją o nieważności takiej umowy ${ }^{46}$.

Do dookreślenia zakresu przedmiotowego zakazu zawierania umów o spadek po osobie żyjącej pomocne powinno być zbadanie granic dopuszczalności tzw. darowizny mortis causa ${ }^{47}$. Sąd Najwyższy w porządkującej wątpliwy stan prawny uchwale z dnia 13 grudnia 2013 roku, sygn. akt III CZP 79/13, a przed nim i po

${ }^{43}$ K. Gromek, [w:] Kodeks rodzinny i opiekuńczy. Komentarz, red. K. Gromek, Legalis/el. 2018, komentarz do art. 47 k.r.o., nb. 16.

44 Ustawa z dnia 25 lutego 1964 roku Kodeks rodzinny i opiekuńczy, tekst jedn. Dz.U. z 2017 r. poz. 682 ze zm., dalej: k.r.o.

45 Umowa zbycia spadku, uregulowana w art. 1052 n. k.c., jest umową o spadek, lecz nie po osobie żyjącej. Por. W. Borysiak, [w:] Kodeks cywilny. Komentarz, red. K. Osajda, Legalis/el. 2018, komentarz do art. 1047 k.c., teza 8.1.; komentarz do art. 1051 k.c., teza 2.

46 Odnośnie do przedmiotowego zakresu omawianego zakazu najszersze omówienie przedstawia W. Borysiak op. cit., komentarz do art. 1047 k.c., tezy 14-20.

47 Warto odnotować, że darowizny tego rodzaju bywają również zwane darowiznami post mortem, dla wyraźnego oddzielenia ich od czynności prawnych mortis causa, ogólnie — na zasadzie art. 1047 k.c. — nieważnych; przy czym cechą wyróżniającą czynności mortis causa miałby tutaj być, obok uzależnienia skutków prawnych takiej czynności od śmierci jednej ze stron, także brak związania stron treścią zdziałanej czynności. Por. W. Borysiak, op. cit., komentarz do art. 1047 k.c., tezy $34-35$. 
nim nauka prawa ${ }^{48}$, wskazywały dobitnie, że darowizna zastrzeżona na wypadek śmierci jest ważna o tyle, o ile jej przedmiotem są konkretne rzeczy i prawa konsekwentnie zatem, ilekroć przedmiotem umowy nie mają być konkretne prawa lub rzeczy (również przyszłe), lecz choćby ułamkowo określony majątek jednej ze stron w chwili śmierci, istnieje istotne podejrzenie nieważności takiej umowy. Dla pełni obrazu trzeba także dodać, że zakaz z art. 1047 k.c. dotyka nie tylko umów rozporządzających, lecz także obciążających, w tym w zakresie ustanowienia prawa użytkowania na całości lub części spadku ${ }^{49}$.

Należy zauważyć, że zobowiązania kształtowane w ramach dożywocia znanego staropolskiemu prawu ziemskiemu miały ex definitione ekwiwalentny charakter. Prowadzi to do wniosku o umownej proweniencji dożywocia staropolskiego. Jak wskazano, prawo austriackie nie zakładało co prawda wzajemności jako konstrukcyjnego wymogu advitalitium, istnieją jednak inne względy świadczące o umownym charakterze tej instytucji. Przy założeniu, że mamy do czynienia $\mathrm{z}$ relacją o umownym charakterze, istotnym pozostaje pytanie, czy należałoby ją uznać za umowę o spadek w rozumieniu art. 1047 k.c.

Konkluzja o przynależności do kategorii umów odnoszących się do spadku jest równoznaczna z przyjęciem wniosku o niedopuszczalności zawierania takich umów na gruncie prawa polskiego (art. 1047 k.c.). Nawet gdyby przyjąć, że do ustanowienia użytkowania dochodzi inter vivos, i nawet gdyby wskutek tego przypisać tak dokonanej czynności przymiot nieodwołalności, próbując doprowadzić do powstania analogii z darowiznami mortis causa konstruowanymi w sposób opisany w uchwale SN o sygnaturze III CZP 79/13, to nadal taka czynność pozostałaby czynnością mającą za przedmiot nie konkretne rzeczy lub prawa, lecz spadek. $Z$ kolei ustanowienie użytkowania na enumeratywnie wyliczonych przedmiotach majątkowych, przynależnych ustanawiającemu na dzień dokonania czynności, byłoby w tej mierze dopuszczalne - być może nawet gdyby wyczerpywało większość przyszłego spadku — zarówno z punktu widzenia restrykcji dotyczących przedmiotu użytkowania, jak i zakazu zawierania umów o spadek po osobie żyjącej.

\section{Ustanowienie advitalitium na drodze zapisu windykacyjnego?}

Jak wspomniano, część doktryny prawa austriackiego dopuszczała ustanowienie advitalitium także w drodze jednostronnej czynności prawnej. Przenosząc tę koncepcję na grunt prawa polskiego, biorąc pod uwagę zasadę braku swobody

48 F. Longchamps de Bérier, Z uwag do metodologii nauki prawa prywatnego: argumenty historyczny, dogmatyczny i prawnoporównawczy na przykładzie darowizny na wypadek śmierci oraz zapisu windykacyjnego, [w:] Prawo obce $w$ doktrynie prawa polskiego, red. A. Wudarski, Warszawa 2016, s. 285-331.

49 Tak W. Borysiak, op. cit., komentarz do art. 1047 k.c., teza 16. 
kształtowania przez strony nieznanych ustawie jednostronnych czynności prawnych $^{50}$ (z pewnością zaś czynności ustanawiających prawa rzeczowe), trzeba uznać, że stosownego instrumentarium dostarcza tylko prawo spadkowe. W tej mierze zaś, w wyniku braku wyróżnienia w prawie polskim instytucji kodycylu, taką czynność należałoby kwalifikować jako testament.

Wypada zatem rozważyć możliwość zastosowania rozwiązań testamentowych znanych prawu polskiemu do osiągnięcia skutku tożsamego z advitalitium austriackim. W tym zakresie interesującym jawi się zapis windykacyjny. Zgodnie $\mathrm{z}$ art. $981^{1} \S 1$ k.c. zapis windykacyjny polega na postanowieniu przez spadkodawcę (w ramach testamentu sporządzonego w formie aktu notarialnego), że oznaczona osoba nabywa przedmiot zapisu z chwilą otwarcia spadku. $\S 2$ tego przepisu doprecyzowuje, że przedmiotem zapisu windykacyjnego może być ustanowienie na rzecz zapisobiercy użytkowania lub służebności. Jest więc legat per vindicationem w polskim ujęciu narzędziem zdolnym do stworzenia prawa rzeczowego ${ }^{51}$ w drodze czynności jednostronnej ${ }^{52}$.

Możliwość jego zastosowania w celu skorzystania z instytucji advitalitium jest jednak ograniczona. Problematyczną pozostaje bowiem możliwość ustanowienia poprzez zapis windykacyjny prawa rzeczowego na całości spadku, a więc na masie majątkowej o przyszłym, nieokreślonym jeszcze zbiorze. Trzeba bowiem zauważyć, że $\S 2$ art. $981^{1}$ k.c. przedmioty zapisu windykacyjnego wymienia taksatywnie. Ustawodawca precyzuje, że przedmiotem legatu może być rzecz oznaczona co do tożsamości (art. $981^{1} \S 2$ pkt 1 k.c.). Punkt $4 \S 2$ art. $981^{1}$ k.c., stanowiący prawną podstawę kreowania prawa użytkowania w drodze zapisu windykacyjnego, również wydaje się zakładać konieczność określenia co do tożsamości rzeczy, na której to ograniczone prawo ma ciążyć. W przeciwnym razie nie byłoby bowiem możliwe powstanie tego prawa z momentem otwarcia spadku.

Kolejnym argumentem świadczącym przeciwko możliwości utworzenia prawa użytkowania na masie majątkowej o niezdeterminowanym ostatecznie składzie jest to, że prawo spadkowe i przepisy o zapisie windykacyjnym nie kreują użytkowania innego niż znane prawu rzeczowemu, innego niż regulowane art. $252 \mathrm{n}$. k.c. Skoro zatem co do użytkowania jako takiego panuje konstatacja o niemożliwości obciążenia w drodze umowy nim masy majątkowej, takiej jak spadek, to

50 Zob. K. Zaradkiewicz, [w:] Kodeks cywilny. Komentarz, t. 2, red. K. Pietrzykowski, Legalis/ el. 2018, komentarz do art. 245 k.c., nb. 35; Z. Radwański, [w:] System Prawa Prywatnego, t. 2. Prawo cywilne - część ogólna, Warszawa 2008, s. 178-180.

51 Zob. J. Kuźma-Sulikowska, Ustanowienie służebności $w$ drodze zapisu windykacyjnego, „Studia Prawa Prywatnego” 2016, nr 2.

52 Acz, z uwagi na konieczność przyjęcia zapisu windykacyjnego (bądź fikcję jego przyjęcia w razie niezłożenia w terminie stosownego oświadczenia), a także fikcję wstecznych skutków oświadczenia o odrzuceniu zapisu, nie sposób uznać, by takie ustanowienie odbywało się bez udziału zapisobiercy, w szczególności, by ostatecznie mogło nastąpić wbrew jego woli. 
konkluzja w odniesieniu do ustanowienia tego prawa poprzez zapis windykacyjny powinna być tożsama.

Z powyższego wynika zatem użyteczność instytucji zapisu windykacyjnego wyłącznie do ustanowienia użytkowania na wypadek śmierci na oznaczonych rzeczach, wchodzących w skład spadku — analogicznie zatem jak przez zastosowanie konstrukcji darowizny mortis causa.

\section{Wnioski}

W świetle niniejszych rozważań należy uznać, że polskie prawo cywilne de lege lata umożliwia spadkodawcom osiągnięcie skutków zbliżonych do advitalitium, znanego z prawa austriackiego, co do poszczególnych składników majątkowych, mających wejść w skład spadku, jednakże nie jest to możliwe co do masy spadkowej, rozumianej jako całość. W tym zakresie zatem wszelkie koncepcje odnoszące się do zastosowania advitalitium we współczesnym prawie polskim muszą być postrzegane $\mathrm{w}$ kategorii postulatów de lege ferenda.

Warto jednak zastanowić się, czy wprowadzenie takiej instytucji do prawa polskiego byłoby celowe? W szczególności, czy advitalitium mogłoby stanowić przydatne narzędzie dla potrzeb kształtowania przez spadkodawcę za jego życia losów majątku spadkowego (tzw. estate planning)? Jaka mogłaby być przydatność takiej instytucji obecnie? Doświadczenie austriackie wydaje się stanowić silny argument negatywny. Kierunek rozwoju austriackiego prawa spadkowego, śledzącego przecież stosowne zmiany społeczne, może być postrzegany jako antycypujący zmiany prawa polskiego ${ }^{53}$.

Należy zauważyć, że advitalitium jest co do genezy instytucją prawną systemu rodowego, nieprzewidującego dziedziczenia przez małżonków, a także nieznającego w ogóle (prawo staropolskie) bądź niestatuującego jako domyślny ustroju wspólności majątkowej małżeńskiej (prawo austriackie). Z tego właśnie powodu i z chęci zabezpieczenia $w$ takim systemie bytu materialnego żony wynikała przydatność omawianej instytucji podówczas. Obecnie w Polsce, gdy małżonek jest najczęściej uprawniony z tytułu wspólności majątkowej (przy założeniu, że majątek wspólny w typowych okolicznościach stanowi masę większą lub przynajmniej równą majątkom osobistym) oraz uprawniony do dziedziczenia - w udziale nie mniejszym aniżeli $1 / 4$ - advitalitium traci sens praktyczny.

Jednak to właśnie w wyłączeniu małżonka z dziedziczenia oraz w odwróceniu założeń leżących u podwalin omawianej instytucji można dopatrywać się okoliczności decydującej o potencjalnej przydatności advitalitium obecnie. Jak się bowiem wydaje, mogłoby ono stać się ciekawym narzędziem dla potrzeb estate

53 Por. K. Bokwa, I. Jarosz, Modernizacja prawa spadkowego na przykładzie prawa austriackiego. Spojrzenie krytyczne, „Kwartalnik Prawo - Społeczeństwo - Ekonomia” 2017, nr 11, s. $12-24$. 
planning. Advitalitium pozwala na zaopatrzenie małżonka na okres jego życia przy jednoczesnym wyłączeniu z dziedziczenia jego, i, co za tym idzie, także jego spadkobierców. Mogłoby to mieć ogromne znaczenie w sytuacji, gdy małżonek ustanawiający advitalitium jest zainteresowany tym, by do dziedziczenia po nim nie doszli spadkobiercy jego małżonka. Jako przykład można tutaj wymienić sytuację, gdy obok dzieci wspólnych jeden z małżonków ma dzieci z innym partnerem i małżonek ustanawiający nie chce, aby dziedziczyły one po nim przez głowę współmałżonka, lub gdy małżonkowie mają dzieci, lecz nie wspólne. Wydaje się, że obecnie, przy rozpowszechnieniu zjawiska rodziny patchworkowej, tego rodzaju konstelacje stosunków rodzinnych będą coraz częściej spotykane.

W tym zakresie można upatrywać sensu odwołania do tradycji advitalitium w XXI wieku. Co paradoksalne, ta ciekawa i trudna do zakwalifikowania, rdzennie polska instytucja, której geneza sięga średniowiecza i która przez zbieg historycznych okoliczności (przypadków?) przez dziesięciolecia egzystowała także u stóp Alp i nad Adriatykiem, dziś mogłaby znów odegrać rolę, acz zgoła odmienną od pierwotnej.

\section{Bibliografia}

Bokwa K., Odszkodowanie oraz zadośćuczynienie w prawie polskim i austriackim. Rys historyczny i prawnoporównawczy, [w:] Pomniki prawa na przestrzeni wieków, red. K. Górski, J. Pokoj, D. Szczepaniak, Ł. Szymura, Kraków 2017.

Bokwa K., Jarosz I., Modernizacja prawa spadkowego na przykładzie prawa austriackiego. Spojrzenie krytyczne, „Kwartalnik Prawo — Społeczeństwo - Ekonomia” 2017, nr 11.

Borysiak W., [w:] Kodeks cywilny. Komentarz, red. K. Osajda, Legalis/el. 2018.

Burzyński P., Prawo polskie prywatne, Kraków 1871.

Dąbkowski P., Prawo prywatne polskie, t. 1, Lwów 1910.

Grodziski S., W Królestwie Galicji i Lodomerii, Kraków 2005.

Gromek K., [w:] Kodeks rodzinny i opiekuńczy. Komentarz, red. K. Gromek, Legalis/el. 2018.

Jaworski W.L, Prawo cywilne na ziemiach polskich, t. 1. Źródła. Prawo matzeńskie osobowe i majątkowe, Warszawa-Kraków 1919.

Kępiński J., Czarnota I., [w:] Kodeks cywilny, t. 1. Komentarz. Art. 1-44911, red. M. Gutowski, Legalis/el. 2016.

Księga Ustaw Cywilnych Wszystkim Niemiecko-Dziedzicznym Kraiom Monarchyi Austryackiey Powszechna, Wiedeń 1811.

Księżak P., [w:] Kodeks cywilny. Komentarz, red. K. Osajda, Legalis/el. 2018.

Kurzkommentar zum ABGB, red. H. Koziol, P. Bydlinski, R. Bollenberger, Wien 2007.

Kuźma-Sulikowska J., Ustanowienie stużebności w drodze zapisu windykacyjnego, „Studia Prawa Prywatnego" 2016, nr 2.

Lakner M., Ueber die Abfassung von Testamenten, so wie über das Erbrecht und die Erbschaftsangelegenheiten, Wien 1853.

Longchamps de Bérier F., Z uwag do metodologii nauki prawa prywatnego: argumenty historyczny, dogmatyczny i prawnoporównawczy na przykładzie darowizny na wypadek śmierci oraz zapisu windykacyjnego, [w:] Prawo obce $w$ doktrynie prawa polskiego, red. A. Wudarski, Warszawa 2016. 
Nippel F.X., Darstellung der Rechte der Ehegatten in Beziehung auf ihr Vermögen, Linz 1824. Ogonowski A., Oesterreichisches Ehegüterrecht, t. 1, Leipzig 1880.

Radwański Z., [w:] System Prawa Prywatnego, t. 2. Prawo cywilne - część ogólna, Warszawa 2008. Sammlung von civilrechtlichen Entscheidungen des k.k. Obersten Gerichtshofes - Achtzehnter Band, red. J. Glaser, J. Unger, J. von Walther, Wien 1883.

Spasowicz W., Pisma, t. 4, Petersburg 1892.

System Prawa Prywatnego, t. 4. Prawo rzeczowe, red. E. Gniewek, Warszawa 2012.

Till E., Obrady trybunatu szlacheckiego w Tarnowie: o t.z.w. galicyjskim kodeksie cywilnym z roku 1797, Lwów 1909.

Wereszycki H., Pod berłem Habsburgów, Kraków 1986.

Winiarz A., Polskie prawo majątkowe-matżeńskie w wiekach średnich, Kraków 1899.

Winiwarter J. von, Das österreichische bürgerliche Recht, systematisch dargestellt und erläutert. Vierter Theil, Wien 1837.

Wróblewski S., Powszechny austryacki kodeks cywilny z uzupetniajacemi ustawami i rozporzadzeniami, objaśniony orzeczeniami Sądu Najwyższego. Część druga (\$\$ 938-1502), Kraków 1918.

Zaradkiewicz K., [w:] Kodeks cywilny. Komentarz, t. 2, red. K. Pietrzykowski, Legalis/el. 2018.

Zeiller F. von, Commentar über das allgemeine bürgerliche Gesetzbuch für die gesamten Deutschen Erblander der Oesterreichischen Monarchie. Dritter Band, Zweyte Abtheilung, Wien-Triest 1813.

\section{An already defunct institution? Old-Polish and Austrian pactum advitalitium in a contemporary perspective}

\section{Summary}

The early Polish institution of advitalitium, designed to help safeguard the financial status of a widowed spouse, resulted not only from social circumstances, but also from the legal determinants: the default separation of martial property and lack of commune marital property system as well as the lack of statutory spousal succession. The institution was later introduced in the modern Austrian civil law, and codified in the Allgemeines bürgerliches Gesetzbuch, with slight modifications allowing the creation of lifetime usufruct not only against the entire estate but also a part thereof as well as several assets only. However, pactum advitalitium thus regulated found minimal popularity and application within the Austrian-ruled domain, evidenced by the lack of case-law regarding the discussed institution. It is then hardly surprising that the provisions governing advitalitium were repealed from ABGB, meeting virtually no objections. This seems reasonable: advitalitium's roots as an institution of old Polish law, arising from the circumstances discussed supra, seem to render it hardly useful nowadays. It is especially so in modern Polish law, taking into account that spouses usually share the commune marital property (which in practice is usually larger than personal assets of spouses) and in most cases are entitled to statutory inheritance in shares, in most cases not smaller than $1 / 4$.

However, it is the exclusion of a spouse from succession, combined with a reversal of presumptions underlying advitalitium, that could render it actually purposeful nowadays. The institution discussed could become a potentially useful instrument of estate planning, allowing to secure the financial well-being of one's spouse, yet excluding from succession not only that spouse but also his or her successors. This could be of vast significance particularly in cases when one is interested in excluding their spouse's successors from succession, e.g. when along with having children together, one of the spouses has children with another person and the spouse establishing advitalitium does not wish that they succeed after him through their parent, or in cases where the spouses have no common children and the spouse establishing advitalitium desires that only his or her 
children inherit, provided however that the espouse if able to use the estate or a part thereof or certain assets for his or her lifetime. Nowadays, taking into account the growing commonness of patchwork-family models, such circumstances will arguably also proliferate.

Hence, it is here that one could identify the sensibility of advitalitium in the 21st century. Ironically, this interesting and hard-to-label, genuine Polish institutions, with its roots reaching the Middle Ages, which, through a number of historical circumstances, had existed also at the foot of the Alps and on the Adriatic coast - could play a certain practical role, though different than historically. 